\title{
Kıyı peyzaj tasarımlarının önemi ve Kurucaşile (Bartın) limanı için öneriler
}

\author{
Importance of coastal landscape designs and suggestions for Kurucasile (Bartın) port
}

\author{
Nurhan KOÇAN *1,a
}

${ }^{1}$ Bartın Üniversitesi Mühendislik Mimarlık ve Tasarım Fakültesi Peyzaj Mimarlı̆̆ı Bölümü 74100 Bartın

\author{
• Geliş tarihi / Received: 23.10.2020 • • Düzeltilerek geliş tarihi / Received in revised form: 12.01.2021 • Kabul tarihi / Accepted: 20.01 .2021
}

\section{$\ddot{O} \mathbf{z}$}

Su kıyıları tarih boyunca insanlar tarafından çeşitli amaçlar için kullanılmıştır. Bu kullanımların en önemlilerinden biri de rekreasyonel kullanımdır. Suyun sahip olduğu görsel ve fiziksel etkilerden çeşitli şekillerden yararlanmak üzere, insanlar serbest zamanlarını su kıyılarında geçirmektedirler. Bu çalışmada Bartın ili Kurucaşile İlçesinde bulunan liman bölgesi çalışma alanı olarak seçilmiştir. Alan güncel durumda yük nakliyesi ve taşımacılık amacıyla kullanılması yanısıra rekreasyonel amaçlar için de gelişigüzel kullanılmakta ve sahip olduğu potansiyel yeterince değerlendirilememektedir. Çalışmada, alanın fiziksel ve görsel olarak daha iyi koşullara ulaştırılması, kent halkı ile ziyaretçilere daha iyi kentsel bir mekan kazandırılması ve rekreasyonel etkinlikler için daha uygun ortamlar hazırlamak hedeflenmiştir. Bu amaçla alan için farklı konseptlerde peyzaj tasarım projeleri oluşturulmuştur. Projelerin hazırlanması ve sunumunda AutoCad 2017, SketcUp, Photoshop CS5 ve Lumion yazılımları kullanılmıştır. Çalışma kapsamında üretilen projelerin uygulanması durumunda alanın mevcut sorunlarını çözeceği, mekânsal kalitenin artacağı ve kullanıcılar için farklı kamusal alan kazanımlarının gerçekleşeceği öngörülmektedir.

Anahtar kelimeler: Bartın, Kıyı kenti, Kıyı tasarımı, Kurucaşile, Peyzaj tasarımı

\begin{abstract}
Water shores have been used by people for various purposes throughout history. One of the most important of these is recreational use. People spend their free time on water shores in order to benefit from the visual and physical effects of water in various ways. In this study, the port area in Kurucasile District of Bartin Province was chosen as the study area. The area is currently used for transportation. Apart from that, it is used indiscriminately for recreational purposes and its potential is not used sufficiently. In the study, it is aimed to bring the area to better physical and visual conditions, to provide a better urban space for the citizens and visitors, and to prepare a facility for recreational activities. For this purpose, landscape design projects in different concepts were created for the area. AutoCad 2017, SketcUp, Photoshop CS5 and Lumion software were used in the preparation and presentation of the projects. It is foreseen that if the projects produced within the scope of the study are implemented, the existing problems of the area will be solved, the spatial quality will increase and different public space will be realized for the users.
\end{abstract}

Keywords: Bartın, Coastal city, Coastal design, Kurucasile, Landscape design

*a Nurhan KOÇAN; nkocan@bartin.edu.tr, Tel:0378 2235144, orcid.org/0000-0001-9433-7007 


\section{Giriş}

Tarihsel süreç içerisinde kentlerin kuruluşunda ve gelişmesinde etkili olan öncelikli unsurlar coğrafi, ekonomik ve askeri nedenlerdir. $\mathrm{Bu}$ nedenlerin önemli ortak bileşeni ise su olmuştur. Su, insanlığın var olmasından bu yana daima insan hayatını kolaylaştıran temel bir unsur olarak savunmadan, ulaşıma, ticaretten sanayiye bir çok önemli görevler üstlenmiştir. En önemlisi ise suyun varlığının, suyla ilişkili yerleşmelerin kültürünün de oluşumunda ve gelişiminde önemli rol üstlenmesidir. Kent ile kıyı arasında tarih boyunca olagelen yakın ilişki süreç içinde kentin hoş, zengin ve önemli bir simgesini oluşturmuştur (Önemli, 2007).

Kuruluşundan bu yana sürekli etkileşim içinde olan kent ve kıyısı arasındaki ilişkiler, çeşitli dinamiklerin etkisiyle süreç içinde çeşitlenmiş, zaman zaman kesintiye uğramış, özellikle sanayileşme süreciyle değişmiştir. Su-kent ve çevresi arasında insan ve eşya akışına dayalı ilişki günümüzde farklı dinamiklerin etkisiyle çeşitlenmiştir. Gelişen teknoloji ve yeni ekonomik politikalarla birlikte, sanayinin kıyı bölgelerinden uzaklaştırılması veya control altına alınması yeni kopan kent-kıyı ilişkilerinin onarımı için firsat yaratmaktadır (Kılıç, 1999). Kıyıların sahip olduğu önemli potansiyeller, her dönemde hem toplum, hem de yabancı turistler ve tüccarlar için çekim kaynağ 1 olmuştur. Yaşamsal fonksiyonlarla donatılmış olan çok zengin aktivitelere sahip olan kıyılar, her dönemde güçlü ilişki içinde oldukları kentte önemli bir gelişim ve değişim unsuru olmuşlardır (Önemli, 2007).

Kıyılar görsel, işlevsel, algısal ve ekolojik nitelikleriyle turistik amaçlara hizmet ederler. Özellikle son y1llarda kentli nüfusun, sağlık, dinlenme, eğlenme ve tatil alışkanlıkları değişmiş artan gelir düzeyleriyle de desteklenen bu alışkanlıklar kıyılara olan talebi arttırmıştır (Önemli, 2007). Ancak bu alanlarda, turizm kullanımlarının ekolojik sistemi bozmadan devam edebilmesi için bir plana ihtiyaç bulunmaktadır. Bunun aracı ise peyzaj tasarım projeleridir. Kıyı bölgeleri, bazen birkaç kullanımı birden içerebilir. Önemli olan kıyılar için seçilecek kullanımların birbiri ile çelişmeden, bir arada ve doğal kaynakların özelliklerini yitirmeyecek oranlarda kapsam ve düzeyde olmasıdır. Kıyılar için verilecek kararlarda ekonomik, fiziksel, biyolojik, sosyal ve kültürel değerler göz önüne alınmalıdır (Doğan ve Erginöz, 1997; Van der Ryn ve Cowan, 1996).
Kentlerin kentsel işlevlerini yerine getirmeleri yanısıra diğer kentlere göre avantajlı duruma gelebilmeleri, kentsel ekonomilerini canlandırmaları, uluslararası sermayeyi ve kamu yatırımlarını çekmeleri ve kent turizminde ön plana çıkma istekleri kentsel projelere olan talebi ve kentsel projelerin önemini artırmıştır (Önemli, 2007).

Kentleri diğer kentlerden üstün ve farklı k1lan; yaşam kalitesi gelişmiş, mekansal bilgi birikimi ve deneyimlerle oluşmuş bir kimlik içeren, çekici ve heyecan verici, güvenli, yenilik yaratıcı bir yer olma özellikleridir. Kentlere ilişkin oluşturulan etkileyici prestij projeleri kentsel girişimciliğin kaynak yaratmada yaygın olarak kullandığı bir araç olmaktadır (Lash ve Urry, 1994). Bu tür projeler, kent için düşünülen imajın gerçekleşmesine yardım eden düşünce ve tasar ürünü bir uygulama aracıdır. Kentsel peyzaj projeleriyle, fiziksel firsatların yanı sıra finansal, politik ve ekonomik potansiyellerin birer firsat olarak ele alınması kentin gelişimini sağlayacaktır (Önemli, 2007). Nitekim Dünyada ve Türkiye'de kıyı alanlarına yönelik yapılan projeler bulundukları alanın gelişimini sağlamış ve kentin prestij noktası olmuşlardır.

Çalışmanın amacı önerilen peyzaj tasarım projeleri ile Kurucaşile ilçesinde yer alan liman bölgesinin fiziksel ve görsel olarak daha iyi koşullara ulaştırılması, kent halkı ile ziyaretçilere daha iyi kentsel bir mekan kazandırılması ve rekreasyonel etkinlikler için daha uygun ortamlar hazırlanmasıdır.

\section{Materyal ve metot}

\subsection{Materyal}

Kurucaşile, Bartın kent merkezine 52 km uzaklıkta Karadeniz kıyısında bulunan bir ilçedir. Kurucaşile Bartın'ın kuzey doğusunda yer alır. Kent Merkezi, Zeytin ve Sandal Burunları ile sinırlanan koylar üzerinde kurulmuştur. İlçe merkezine ulaşım Amasra ve Cide yönünden karayolu ile sağlanır (Kurucaşile Belediyesi, 2020) (Şekil 1).

Kurucaşile, Küre dağlarının batı uzantıları üzerinde olup ortalama yüksekliği 300 metre civarındadır. Yükseltiler Kurucaşile'ye ulaşımı oldukça zorlaştırmaktadır. Kurucaşile, eğimli bir araziye sahiptir. Eğimdeki bu fazlalık bitki örtüsünün tahrip edildiği yerlerde erozyonu beraberinde getirmiştir. İlçe yüzölçümünün \%61'ini ormanlık alandır. Ormanlarda kayın, gürgen, kestane, meşe, karaçam, sarıçam, köknar, kiraz, akçaağaç, dişbudak, çınar, ıhlamur, defne, yabani findık, kuş 
üvezi, ahlat, muşmula, kızılcık, ardıç ağaçları bulunmaktadır. Çalı, ağaçcık ve otsu bitkiler ise, orman gülü, eğrelti, ayı üzümü, bögürtlen, karaçalı, alıç, kuş üzümü, sumak, kocayemiş, taflan, kuşburnu, kartopu, çoban püsküllü, baldıran otu, ballı baba, eşek dikeni, gelincik, isırgan, kabalak otu, köy göçüren, çuha çiçeği, sığır kuyruğu, kardelen, sıklemen, yonca, sütleğen dilcik, katır tırnağı, sarmaşık, binbir delik otudur (Kurucaşile Kaymakamlığı, 2020).

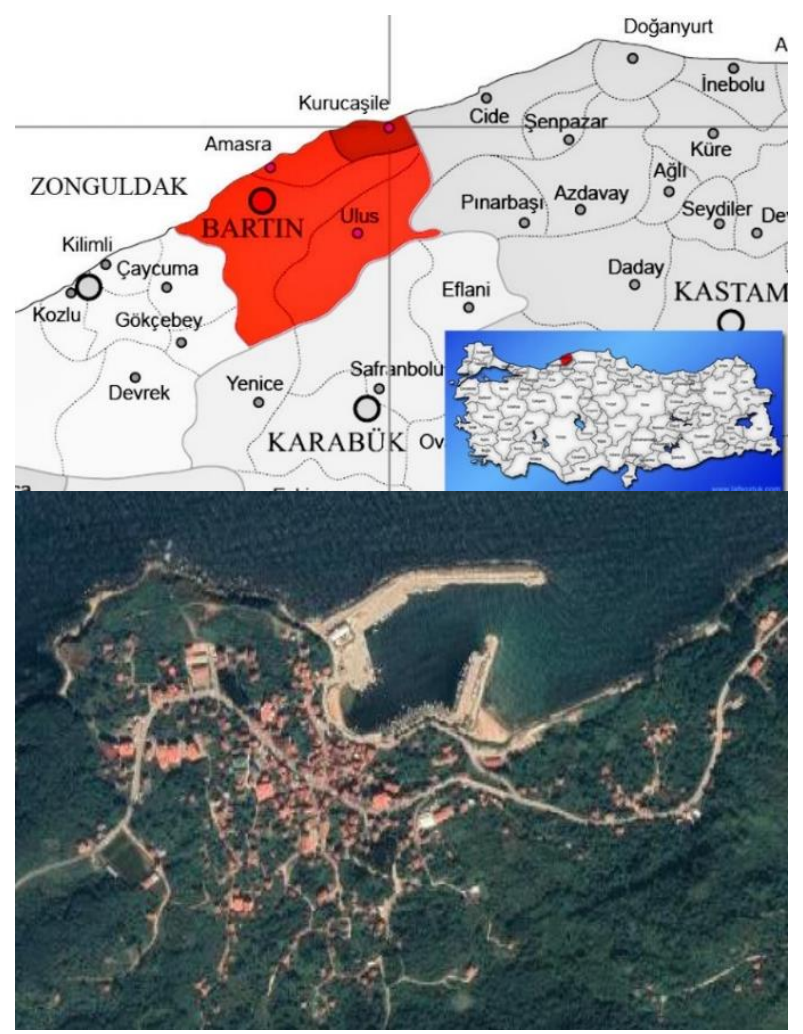

Şekil 1. Çalışma alanının konumu (Google map, 2020a; Google map, 2020b)

İlçede tipik Karadeniz iklimi hakim bulunmaktadır. Buna göre kışları soğuk ve yağışlı yazları ise 11 k ve yağışlı geçmektedir. Yıllık yağış oranı 1072 mm, yillık ortalama sicaklık $13.1^{\circ} \mathrm{C}$, en sicak ay $23^{\circ} \mathrm{C}$ ile Temmuz, en soğuk ay $4.2^{\circ} \mathrm{C}$ ile Aralıktır. Ortalama bağıl nem \% 77dir. En hızlı rüzgar yönü Kuzey'dir (Kurucaşile Belediyesi, 2020).

Kurucaşile nüfusu 2019 yılına göre 6.621'dir. Bu nüfus, 3.408 erkek ve 3.213 kadından oluşmaktadır. Yüzde olarak ise nüfusun \%51.47'1 erkek, \%48.53'ü kadındır. İlçe nüfusunun büyük bir bölümü tarım ve hayvancılığın yanı sıra, maden işçiliği ile ahşap tekne yapımcılığ 1 ile geçimlerini sağlamaktadır. Kurucaşile ahşap tekne yapımcılığ 1 konusunda yurt içinde ve yurt dışında önemli bir yeri vardır. Kurucaşile'de son 30 yıla kadar Osmanlı donanmasının savaş gemilerinden, yük gemilerine kadar pek çok gemi tipi yaratılmıştır.
Yük gemisi, balıkçı teknesi vey at bunlar arasındandır. İlçede balıkçılık da fazlaca yapılmaktadır. Balıkçılıkla geçimini sağlayan nüfusun oranı oldukça yüksektir. İlçenin en önemli gelir kaynaklarından birisi de findıktır (Kurucaşile Belediyesi, 2020; Kurucaşile Kaymakamlığı, 2020).

Çalışma alanı Bartın ili Kurucaşile ilçesinde yer alan liman bölgesidir. Alan yaklaşı $60000 \mathrm{~m}^{2}$ büyüklüktedir. Alan ilçede oturan sakinler ve farklı şehirlerden gelmiş üniversite öğrencileri tarafından kullanılmaktadır. Yazın ise denize girmek için gelen insanların da gelmesiyle alanın iki aylık sürede yoğun olarak kullanıldığı görülmektedir (Şekil 2).
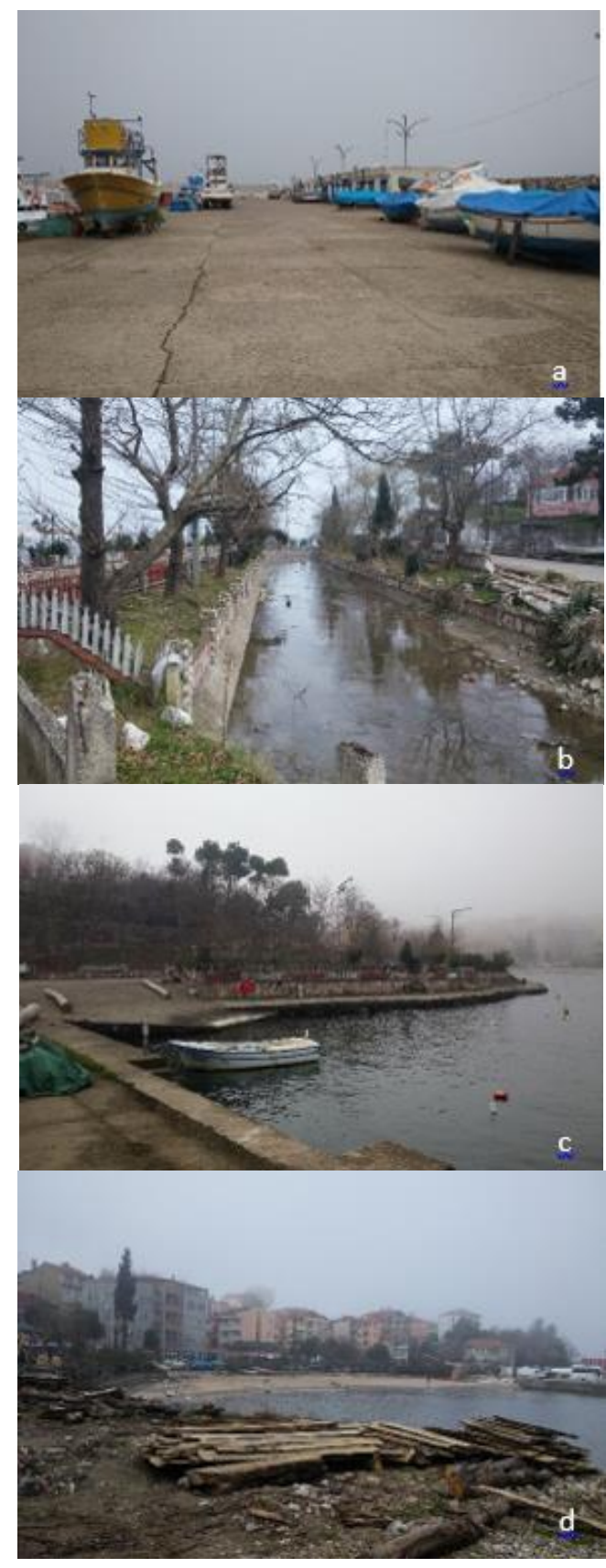

Şekil 2. (a-d) Proje alanından görünümler 
Kurucaşile'nin ilçe olması sebebiyle yaşam olanakları ve ihtiyaçlara erişim bakımından çalışma alanı elverişli durumdadır. Alanda mevcut durumda mini parklar ve kafeteryalar haricinde rekreasyon ve dinlenme alanları bulunmamakla birlikte balıkçı barınağı bulunmaktadır. $\mathrm{Bu}$ barınaklar yat turizmi için elverişlidir. İlçenin kuzeyini Karadeniz oluşturduğundan plaja sahiptir. $\mathrm{Bu}$ plajlarda kent halkı ve ziyaretçiler denize girmektedir. Alanın deniz kenarında olması doğal bir manzara açısından potansiyel niteliğindedir. Alanın tasarım yapabilme ve farklı kullanımları alana getirebilme açısından geniş olması da bir avantaj durumudur. Alanda kötü görüntüye sebep olan çalıların ve çöplerin bulunması, mevcut durumda yeterli alt yapisinın bulunmaması dezavantaj yaratmaktadır.

\subsection{Metot}

Çalışmada öncelikle konuya ve çalışma alanına ilişkin literatür taraması yapılmıştır. Daha sonra çalışma alanında yerinde yapılan gözlem ve incelemelerle alandaki sorunlar tespit edilmiş ve ihtiyaçlar belirlenmiştir. Sörvey çalışmasından sonra alanın mevcut durumu ile sahip olduğu potansiyeller değerlendirilerek bir konsept belirlenmiş ve bu konsepte göre alan kullanım kararları ile tasarım ilkeleri belirlenmiştir. 1/1000 ölçekli imar planı ve Google Earth görüntüleri kullanılarak çalışma alanı sınırları dahilinde ihtiyaç programları pafta üzerine işlenmiştir. Eskiz çalışmaları yapılarak el çizimi ile tasarım alternatifleri üretilmiştir. Kesinlik kazanan proje çizgileri AutoCad 2017 programı kullanılarak bilgisayar ortamına aktarılmıştır. Projenin nihai hali, SketchUp ve Lumion yazilımiyla modellenmiş ve projenin üç boyutlu görselleri elde edilmiştir. Çalışmada bu şekilde üretilen dört öneri proje sunulmuştur.

\section{Bulgular}

Alan, alanın daim kullanıcıları olan ilçe sakinleri ile günübirlik ve mevsimlik ziyaretçilerin ihtiyaçları göz önüne alınarak, yılın her mevsimi düşünülerek tasarlanmıştır. Projelerde her yaş grubunun kullanabileceği mekanlar oluşturmak istenmektedir.

\section{1 Öneri proje 1}

\section{Konsept: Doğa ve İnsan}

Çalı̧̧mada bu konseptin seçilmesindeki amaç; insanın doğa üzerinde kurduğu baskıyı ve doğaya olan etkisini pozitif biçimde dengelemektir.
Çalışmada çocukların; toprağa dokunan, ağaç dalları ve kütüklerle oynayan, eğitsel ve düşünsel becerilerini arttırmayı hedefleyen, yetişkinlerin ise dalından sebze meyve toplayıp yemenin zevkini yaşayabileceği mekanlar oluşturmak amaçlanmıştır.

İhtiyaç Listesi: Ahşap teras $\left(275 \mathrm{~m}^{2}\right)$, dinlenme ve rekreasyon alanı $\left(800 \mathrm{~m}^{2}\right)$, çocuk oyun alanı $\left(150 \mathrm{~m}^{2}\right)$, otopark $\left(150 \mathrm{~m}^{2}\right)$, meydan $\left(300 \mathrm{~m}^{2}\right)$, amfi $\left(450 \mathrm{~m}^{2}\right)$, yüzen sahne $\left(100 \mathrm{~m}^{2}\right)$, plaj $\left(100 \mathrm{~m}^{2}\right)$, plaj spor alanları $\left(150 \mathrm{~m}^{2}\right)$, kiyı rekreasyon alanı $\left(400 \mathrm{~m}^{2}\right)$, mevcut park yenilenmesi $\left(110 \mathrm{~m}^{2}\right)$, tekne çekek yeri $\left(75 \mathrm{~m}^{2}\right)$, restaurant $\left(125 \mathrm{~m}^{2}\right)$, fener kafe $\left(200 \mathrm{~m}^{2}\right)$

Alana girişte bir meydan ve bu meydanı takip eden iki yönde amfi yerleştirilmiştir. $\mathrm{Bu}$ amfiler birbirine bağlantılı basamaklar şeklindedir. $\mathrm{Bu}$ amfilerin önüne bir yüzen sahne yerleştirilerek bu sahnenin değişik amaçlarla (tiyatro, konser vb.) kullanılması düşünülmüştür. Meydanı takip eden yolda otopark bu otoparkin arkasinda tampon görevinde yaşil bant yerleştirilmiştir. Meydanı takip ederek çocuk oyun alanı, dinleme ve rekreasyon alanı düşünülmüş bu dinlenme alanı ahşap terasla tamamlanmıştır. Meydandan geçen ve doğu yönüne doğru ilerleyen aks takip edildiğinde plaj ve plaj aktiviteleri (voleybol, futbol vs.) için alan ayrılmıştır. Yine bu alanın deniz kıyısı tarafina bir adet teras ve bu terası takip eden bir amfi tasarlanmıştır. Bu amfi içerisinde seyyar satıcılar için yerler ayrılmıştır. Mevcutta bulunan balıkçı barınakları ve bunların arka taraftaki kıyı manzarasına bakan alan 'Kı1 Restorant' ve ön tarafinda da tekne çekek yerleri konumlandırılmıştır. Deniz fenerinin olduğu yer 'Fener Kafe' konseptli bir kafeye dönüştürülerek burada da bir manzara seyir noktas 1 oluşturulmuştur. Alanda kıyı boyunca devam eden bir yol aksı tasarlanmıştır. Kurucaşile kıyısını yeniden düzenlemek amacıyla yapılan bu tasarım projesinde alanda mevcut bulunan iki adet giriş korunmuştur ve alana girişler yine bu noktalardan sağlanacaktır. Alana güneybatı cephesinden girildiğinde solda 110 araçlık bir otopark konumlandırılmıştır. Otopark çevresi araçlara da gölge oluşturması amaciyla ağaçlarla çevrelenmiştir. Otoparkın ön bölümünde bir meydan planlanmıştır.

Meydan ile deniz arasında bağlantı birbirini takip eden 3 adet amfi ile sağlanmıştır. Bu amfiler gerek gösteriler sırasında gerekse güneşlenmek ve dinlenmek gibi farklı aktiviteler amaciyla kullanılabilecektir. İkinci amfinin önünde 1 adet yüzen sahne düşünülmüştür. $\mathrm{Bu}$ sahne yine farklı 
gösterilere ev sahipliği yapmak adına tasarlanmış ve amfi ile desteklenmiştir. Meydandan kuzey yönüne ilerlendiğinde sol tarafta bir adet futbol sahası ve bir adet boş saha tasarlanmıştır. Boş birakılan saha farklı spor faaliyetlerinde kullanılabilecektir. Spor alanlarından sonra kıyı boyunca devam eden ahşap zemin ile birleştirilmiş ve içerisinde tepe bulunan bir alan oluşturulmuştur. $\mathrm{Bu}$ tepe ile birlikte alanda kot farklılikları oluşturularak hareket sağlanmış ve farklı manzara noktaları oluşturulmuştur. Güneybatı girişinden alanın doğu yönüne doğru kıyı boyunca kumsal ve araç yolunu takip eden ahşap bir yürüyüş band1 oluşturulmuştur. Bu band sayesinde denizden çıkan insanlar direk araç yoluna çıkmadan yürüyüş
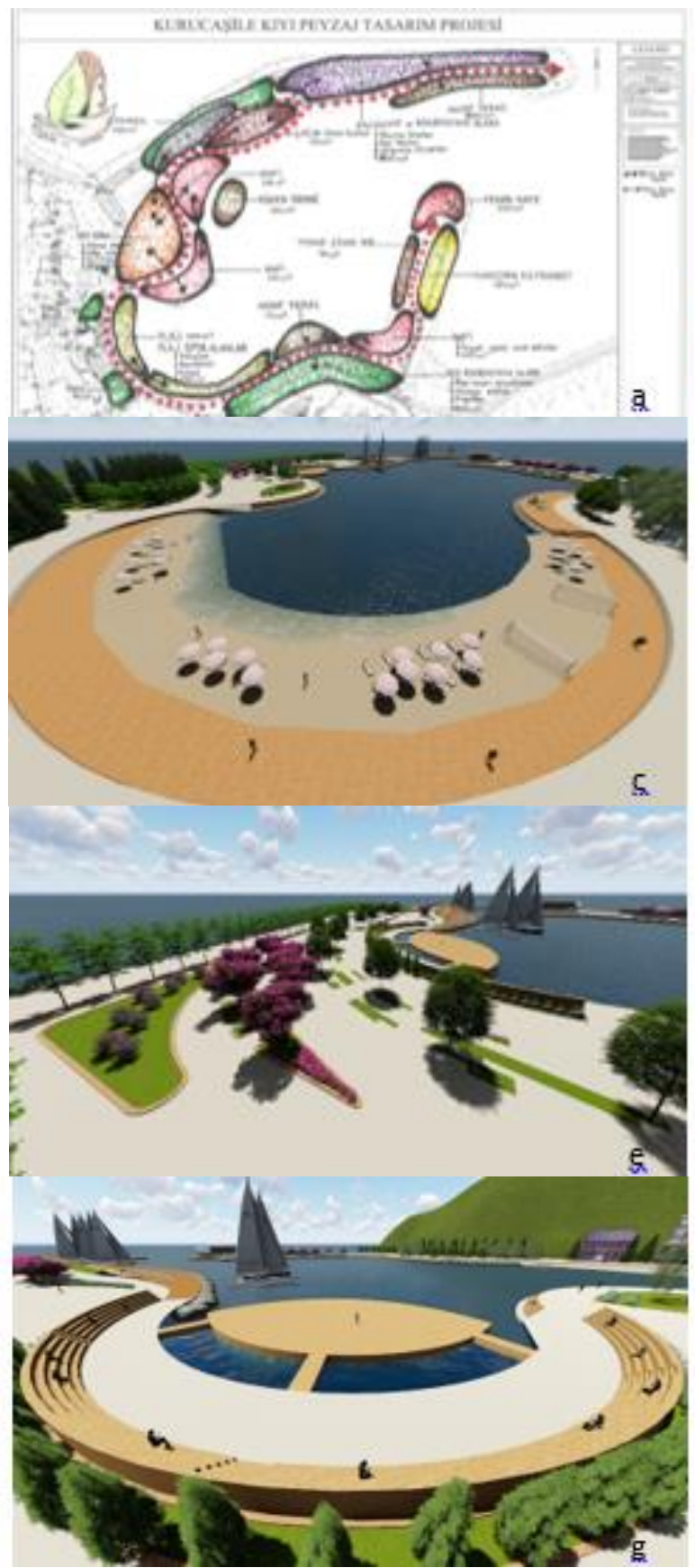

yapabilme firsatı bulacaklardır. Alanın doğu bölümünde bulunan ve denize bağlanan derenin çevresi de onarılmıştır. Kıyıya yürüyüş yolları, karşıya geçişler için iki adet köprüyle beraber su üzerinde taş zeminler oluşturulmuştur. Yine bu bölümde denize bakan kısımda ahşap bir teras ve terası takip eden bir amfi ile bütünlük sağlanmıştır. Amfiden sonra oluşturulan küçük çim tepelerin denize bakan bölümleri tekne çekek yeri olarak değerlendirilmiştir. $\mathrm{Bu}$ band ilerde bir iskeleye dönüştürülmüsstür. Mendireğin en sonuna manzara özelliğinden de yararlanarak yarı cam yarı ahşap malzemeden tasarlanmış 'Fener Kafe' oluşturulmuştur (Şekil 3).

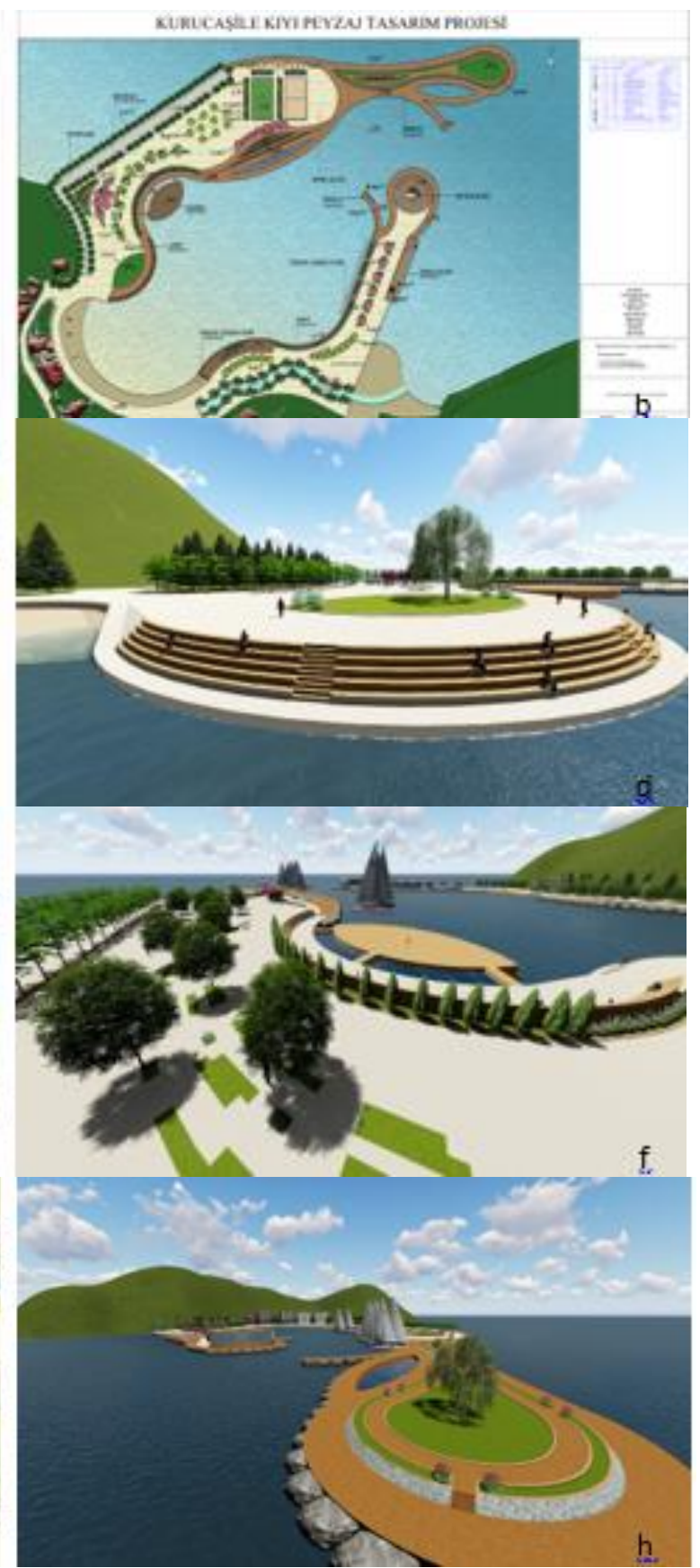

Şekil 3. (a-h). Öneri proje 1 den görünümler 


\section{2 Öneri proje 2}

Konsept: Dalga

Dalga konsepti ile informal tasarımlar yaparak su etkinin karada da devamının sağlanması düşünülmüştür. Dalganın akıcı ve rahatlatıcı etkisini alan kullanıcılarına yansitmak planlanmıştır.

İhtiyaç Listesi: Kafeterya $\left(150 \mathrm{~m}^{2}\right)$, seyir teras1 $\left(30 \mathrm{~m}^{2}\right)$, restoranlar $\left(200 \mathrm{~m}^{2}\right)$, parklar $\left(600 \mathrm{~m}^{2}\right)$,
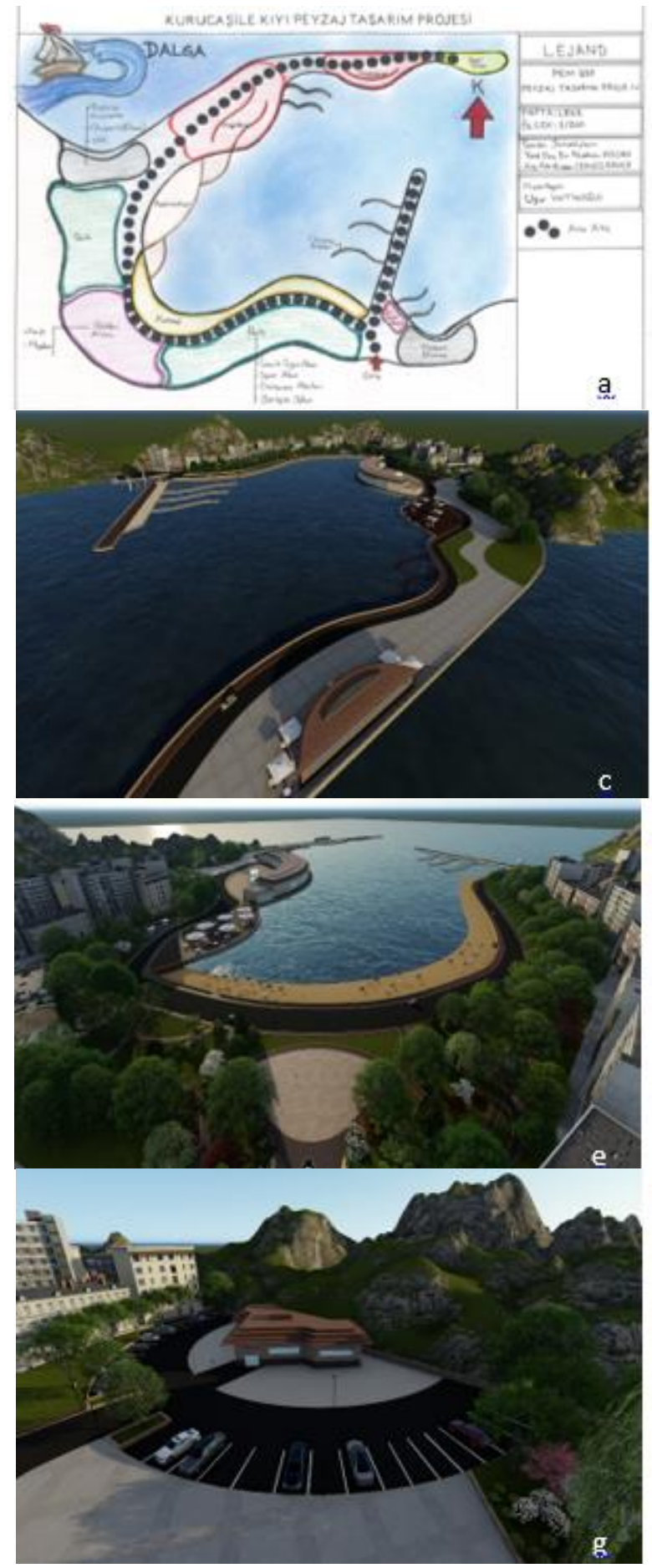

otoparklar $\left(200 \mathrm{~m}^{2}\right)$, su spor alanı, gösteri alanı $\left(250 \mathrm{~m}^{2}\right)$

Alana hareket katmak için keskin hatlara sahip kıyı kesimi dalga konsepti doğrultusunda informal tasarımlar ile yeniden şekillendirilmiştir. Alanın girişinde otopark düşünülmüştür. Alanda bulunan parklar genişletilerek yenilenmiş böylece yeşil dokuyu artırılmıştır. Park içinde çocuk oyun alanları, spor alanları, dinlenme alanları, yürüyüş yolları gibi alanlara yer verilmiştir (Şekil 4).
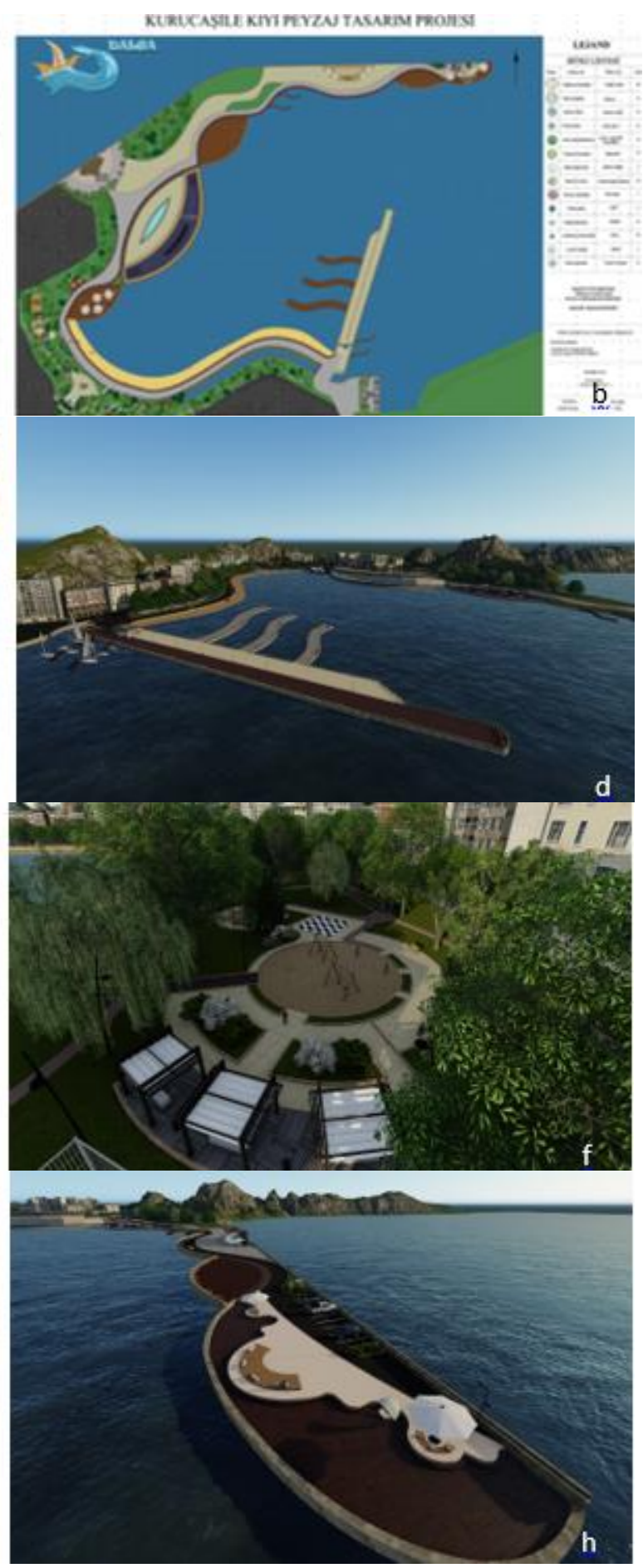

Şekil 4. (a-h) Öneri proje 2 den görünümler 
Üzerinde oturma alanlarının bulunduğu iskeleler tasarlanmıştır. Gösteri, şenlik gibi etkinlikler için amfi formunda bir gösteri alanı düşünülmüştür. Hem kent insanı hem de dişarıdan gelecek kullanıcılar için deniz kıyısında restoran ve kafeteryalara yer verilmiştir. Sahilde insanların yüzebileceği bir plaj oluşturulmuştur. Su sporları için alan ayrılmıştır. Projenin büyük bölümünü kapsayan parkta konsept doğrultusunda birçok yürüyüş yolları tasarlanarak kullanıcıların yeşil doku içinde iyi vakit geçirmeleri amaçlanmıştır. Mevcutta bulunan mendireğin en son noktasında seyir terasına yer verilerek kullanıcılar için fotoğraf çekim noktası ve manzara seyri için alan oluşturulmuştur (Şekil 4).

\section{3 Öneri proje 3}

\section{Konsept: Rota}

Kurucaşile kıyı peyzaj tasarım projesinde konsept olarak "Yıldız" düşünülmüştür. $\mathrm{Bu}$ konsept projemizde çizgisel olarak görülüp ön planla olacaktır. Aynı zamanda projede 'Engelsiz Sahil' düşünülmüştür. Alan içinde uygulanacak olan tasarımlar her kesimden insana hitap edecek şekilde olacağı için bu konsepte karar verilmiştir.

İhtiyaç listesi: Otopark $\left(200 \mathrm{~m}^{2}\right)$, karşılama alanı $\left(250 \mathrm{~m}^{2}\right)$, spor alan $1\left(300 \mathrm{~m}^{2}\right)$, teras $\left(50 \mathrm{~m}^{2}\right)$, kafe $\left(100 \mathrm{~m}^{2}\right)$, restaurant $\left(150 \mathrm{~m}^{2}\right)$, açık hava sinemas 1 $\left(100 \mathrm{~m}^{2}\right)$, sergi ve satış stantları $\left(100 \mathrm{~m}^{2}\right)$, çocuk oyun alan $1\left(150 \mathrm{~m}^{2}\right)$

Alana girişte yıldız formunda denize çıkıntısı olan bir karşılama alanı düşünülmektedir. Meydanda bitki kasaları, bilgilendirme panoları bulunup sert zemin döşeme farklılıklarıyla yönlendirmeler amaçlanmıştır. Meydanın hemen yanında 35 araçlık otopark planlanmıştır. Meydandan devam ettiğimizde iki alternatif yol bulunup hem amfiye ulaşım hem de seyir terasına ulaşım sağlanacaktır. Spor alanında basketbol ve futbol sahaları minyatür olarak düşünülmüştür. Buradaki oyunları ister amfiden ister seyir terasından izleme firsat1 sunulacaktır. Projede sahil kısmında engelli insanlar için özel bir mekan planlanmıştır. Otopark ulaşımın kolay olması için hemen sahilin arkasında konumlandırılmıştır. Alanın kuzeybatısında zemin ile aynı seviyede denizde ayakları bulunan teras konumlandırılmıştır. $\mathrm{Bu}$ mekandan denize girilebilecektir. Ayn1 zamanda terasa oturma alanlar1 ve bitki kasaları eklenecektir. Teras seyir noktası ve güneşlenme alanı olarak da kullanılabilecektir.
Tekne atölyeleri eski yerlerinden kaldırılıp sahilin doğu kısmına alınmış burada atölyelere ait çekek yeri, sergi alanı, ziyarete gelen insanlar için küçük çaplı üretimler için alan düşünülmüştür. Ana aksdan devam edince alanın doğusunda uç kısımda kafe düşünülmüştür. Kafenin yanında bulunan alanda dinlenme ve rekreasyon alanı planlanıp sahil ile olan iç kesimlerde hem estetik amaçlı hem de alanla bağlı olacağı düşünülerek engelsiz kıyı kullanımlarına uyumlu olarak teras tasarlanmıştır. $\mathrm{Bu}$ alanların yanında hakimiyet ve gözlem açısı rahatlığından dolayı çocuk oyun alanı tasarlanmıştır. Devamında rekreasyon alanı ve kültür yolu bulunmaktadır. Bu alanlarda ise denize giriş noktası, satış stantları, sokak müzisyenleri için düşünlen mekan, duvar boyama alanları yer almıştır. Sahilde ekstra olarak voleybol sahası, güneşlenme yerleri ve yarım ay şeklinde iskele tasarlanmıştır. Sahilden çıkıldığında arkadlı yoldan geçildiğinde balıkçı teknelerinin sı ğınması için iskele tasarlanmıştır. $\mathrm{Bu}$ alanda aynı zamanda fitness gibi spor aletleri de konumlandırılmıştır. Yaz ve ilk bahar akşamları için alanda açık hava sineması düşünülmüştür. Bu alanda belirli günlerde ise yerel halk pazarı kurulması amaçlanmıştır. En uç kısımda ise restaurant bulunup eğimli şekilde gelen çatı bahçesi kısmından restaurantın terasına çıkılabilmesi sağlanmıştır (Şekil 5).

\section{4 Öneri proje 4}

\section{Konsept: Rengarenk}

Konsept, denizin mavisiyle birlikte her mevsim renklenen bitkiler ile çeşitli kent dontalıları ve farklı renkte yüzey kaplamaları ile görsel şölen oluşturulması sebebiyle seçilmiştir.

İhtiyaç Listesi: Meydan $\left(300 \mathrm{~m}^{2}\right)$, aktif rekreasyon alanı $\left(250 \mathrm{~m}^{2}\right)$, seyir iskelesi $\left(50 \mathrm{~m}^{2}\right)$, plaj, çay bahçesi $\left(100 \mathrm{~m}^{2}\right)$, oturma alanı $\left(150 \mathrm{~m}^{2}\right)$, balıkçı barınağı $\left(100 \mathrm{~m}^{2}\right)$, çocuk oyun alanı $\left(300 \mathrm{~m}^{2}\right)$, bisiklet ve yürüyüş yolu

Projede otoparka yakın olarak planlanan meydan birçok etkinliklerin düzenlenebilmesi amacıyla oluşturulmuştur. $\mathrm{Bu}$ alanda ağaç altı oturma birimleri bulunmaktadır. Meydanın deniz manzarasına hakim noktasında restoran ve kafeler bulunmaktadir.

Alanda oluşturulan aktif rekreasyon alanında voleybol, tenis gibi spor aktivitelerinin yapılabileceği bir alan oluşturulmuştur. Bu alan genellikle gençlerin kullanabileceği bir mekan olacaktır. 

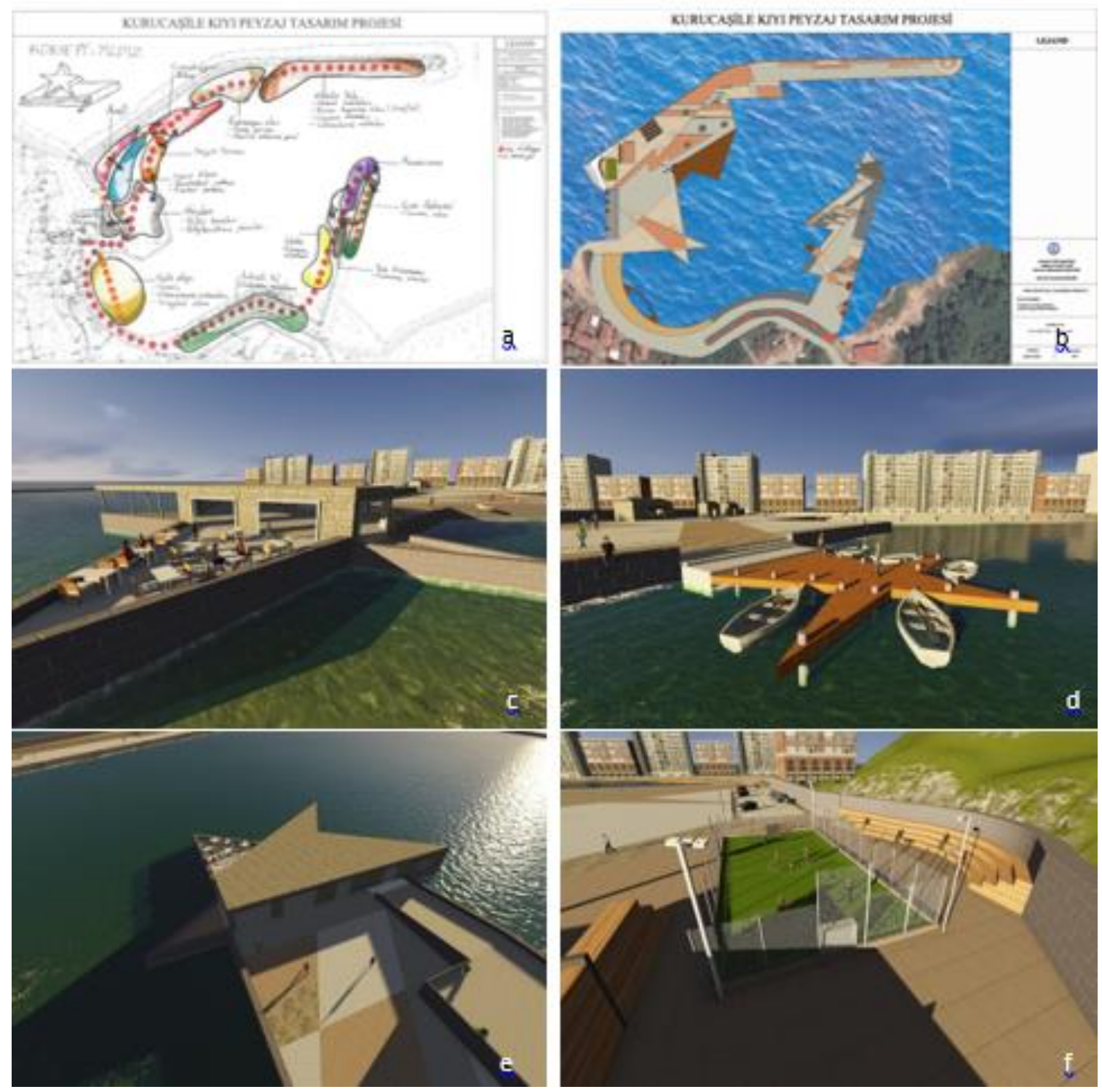

Şekil 5. (a-f). Öneri proje 3 den görünümler

Ahşaptan ve kıvrımlı olarak deniz manzarasının seyri için bir iskele uygun görülmüştür. Bu iskelede insanlar oturup deniz manzarasinı seyredebilecekler ve dinlenebileceklerdir. Plaj alanın da ahşaptan yapılmış soyunma kabinleri bulunmaktadır. Soyunma kabinine yakın wc yer almaktadır. Plaj kenarında gerekli malzemelerin satılabileceği satış birimleri konumlandırılmıştır. Çay Bahçesi seyir iskelesine yakın konumdadır. Alan da bitkilendirme ile birlikte mor renk tonlarında oturma birimleri kullanılmıştır. Balıkçı barınağı tekne çekek yerine yakın olarak konumlandırılmıştır. Barınak balıkçıların

kayıklarını bıraktıkları, av araç ve gereçlerini depoladıkları bir alan olacaktır. Çocuk oyun alanında renkli oyun elemanları kullanılmıştır. Denizin hemen yanında bulunan çocuk oyun alanında bitkisel perdeleme yapılmıştır. Bisiklet ve yürüyüş yolu deniz manzarasını seyretmek için sahil kenarına planlanmıştır. Yol boyunca gölgeleme amaçlı ağaçlandırma yapılmıştır. Ahşaptan ve kıvrımlı olarak deniz manzarasının seyri için yapılmış bir seyir iskelesi mor renkli bitkiler ve banklarla birlikte kullanılarak alanda ilgi çekici olması sağlanmıştır (Şekil 6). 

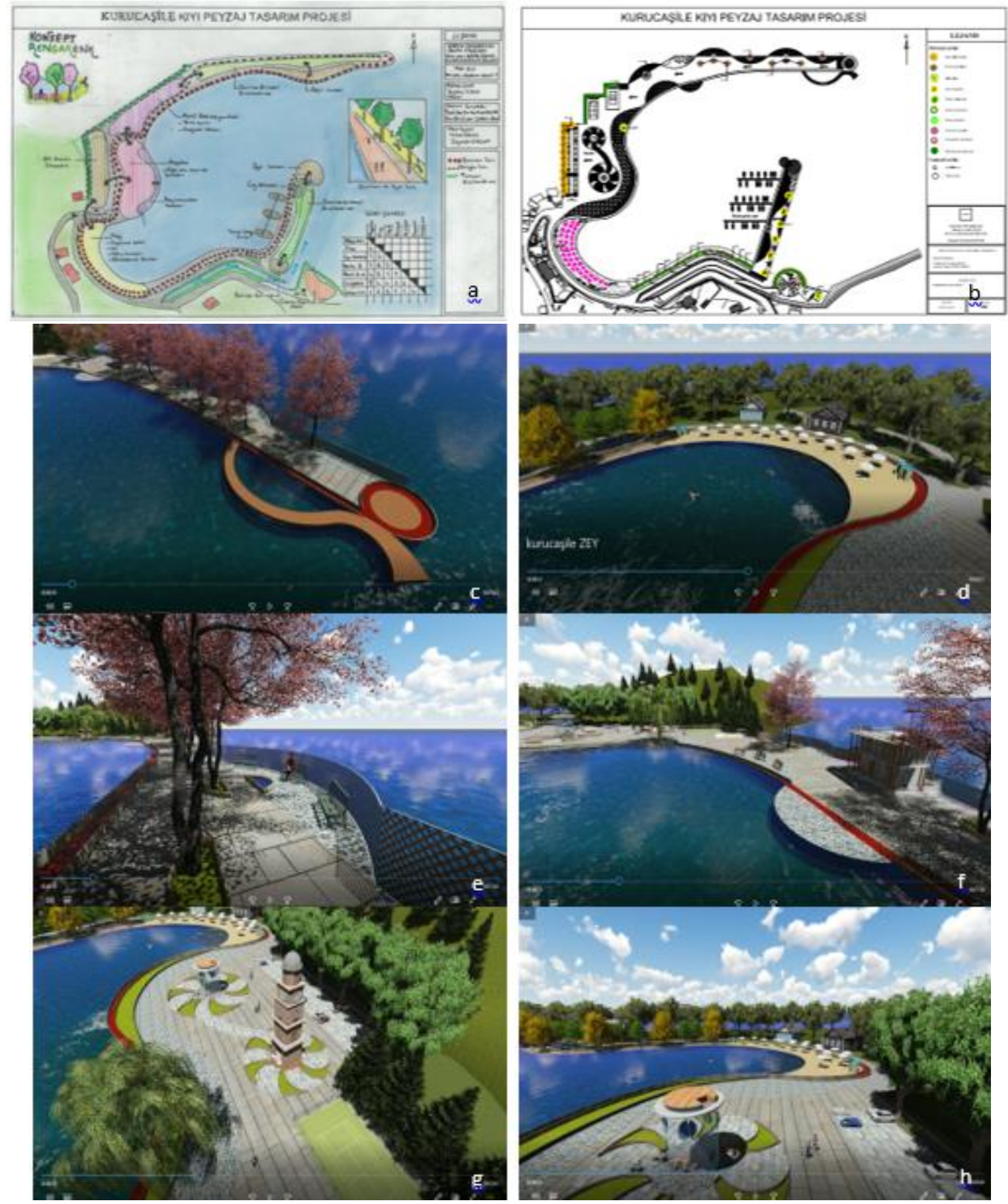

Şekil 6. (a-h) Öneri proje 4 den görünümler

\section{Sonuçlar}

Öneri projelerde ortak ihtiyaçlar temelinde farklı bitkisel ve yapısal elemanlar ile tasarım çizgileri olan projeler ortaya çıkarılmıştır. Proje önerileri; doğal ve kültürel değerlerin korunmasına yönelik fikirler ile mekan zenginliği (çeşitliliği) açısından değerlendirmeye alınmıştır. Seçilen tasarım alternatiflerinde öncelikle projeden beklentiler belirlenmiştir. Alanda bulunan sorunların giderilmesi, mevcut potansiyelin geliştirilmesi ve

kullanıcıların istek ve ihtiyaçlarının karşılanmasında konsept dahilinde çözümler üretilmiştir.

Öneri peyzaj tasarımlarında uyulan genel planlama ilkeleri şöyledir:

- Projelerde alanın fiziksel ve görsel kalitesinin artması, öneri rekreasyon alanları ile ziyaretçi kapasitesinin artırılması ve kent ekonomisine katk1 sunması hedeflenmiştir.

- Alanda küçük ticaret birimleri önerilmiş, zanaatlara yönelik aktivite alanları planlanmıştır. 
- Alanda 1. ve 2. dereceden yaya ulaşımı ön planda tutulmuş, bisiklet yolları düşünülmüştür.

- Alana getirilen yapılarda alanın tarihi değerine uygun, doğal algıyı güçlendiren yapılar tercih edilmiştir.

- Alanda geniş yeşil alanlar oluşturularak bitkisel tasarımlar önerilmiştir.

- Otopark alanlarının tasarlanması ile alan çevresindeki araç yoğunluğunun ve alan içinde taşıt kullanımının azaltılması düşünülmüştür.

- Güncel durumda gece kullanımı kısıtlı olan alan kent halkı ve kullanıcıları için güvenlik sorunu oluşturmaktadır. $\mathrm{Bu}$ nedenle alanda gece aydınlatmaları da tasarlanarak alanın günün her saatinde güvenli olarak kullanılabilmesi ve canlılığı sağlanmıştır.

Tablo 1'e bakıldığında önerilen 4 konsept projenin alanda ihtiyaç olarka görülen ve kullanıcılar tarafından belirtilen kullanımları karşıladığı görülmüştür. Çalışmada önerilen projelerin gerçekleşmesi durumunda alan kent halkı ve ziyaretçiler için kent kimliğine yeni bir referans olacak, söz konusu alanda yaşayanların kentsel yaşamını zenginleştirici bir rol üstlenecektir.

Tablo 1. Öneri projeler ve kullanım alanları (* projede var olduğunu göstermektedir)

\begin{tabular}{lllll}
\hline $\begin{array}{l}\text { Öneri Projeler } \\
\text { Kullanım alanları }\end{array}$ & Öneri proje 1 & Öneri proje 2 & Öneri proje 3 & Öneri proje 4 \\
\hline Amfi & $*$ & $*$ & $*$ & $*$ \\
Balıķı barınağı & $*$ & $*$ & $*$ & $*$ \\
Bisiklet yolu & & & & $*$ \\
Çocuk oyun alanı & $*$ & $*$ & $*$ & $*$ \\
Dinlenme ve rekreasyon alanı & $*$ & $*$ & $*$ & $*$ \\
Kafe & $*$ & $*$ & $*$ & $*$ \\
Meydan/gösteri alanı & $*$ & $*$ & $*$ & \\
Otopark & $*$ & $*$ & $*$ & $*$ \\
Park & $*$ & $*$ & & $*$ \\
Plaj spor alanı & $*$ & $*$ & $*$ & $*$ \\
Restaurant & $*$ & & $*$ & $*$ \\
Sergi ve satış stantları & & $*$ & $*$ & $*$ \\
Seyir terası & $*$ & $*$ & $*$ & $*$ \\
Spor alanı & $*$ & $*$ & & $*$ \\
Tekne çekek yeri & $*$ & & & $*$ \\
\hline
\end{tabular}

\section{Teşekkür}

Çalışmada emeği geçen Şeyma Kahraman, Uğur Hatinoğlu, Ömer Mercimek ve Zeynep Erçen'e teşekkürlerimi sunarım.

\section{Kaynaklar}

Doğan, E. ve Erginöz, M.A. (1997). Türkiye'de Klyl Alanları Yönetimi ve Yapılaşması. İstanbul, Arion Yayınevi.

Google map (2020a, 10 Eylül). Kurucaşile Haritas1, Erişim adresi https://www.google.com.tr/search?q=kuruca\%C $5 \% 9$ File+harita\&sxsrf=

Google map (2020b, 11 Eylül). Kurucaşile Uydu Görüntüsü, Erişim adresi, https://www.google.com.tr/maps/place/Kuruca \%C5\%9File,+Bart\%C4\%B1n/@41.8431572,32. $7152462,15 \mathrm{z} /$.

Kılıç, A. (1999). Klyıdan geri çekilme sürecinde kentkıyı ilişkisi, kentsel kıyı tanımı ve bu kavrama dayal kentsel kiyl gelişme stratejileri: İstanbul örneği. Doktora Tezi, Y1ldı Teknik Üniversitesi, İstanbul.

Kurucaşile Belediyesi. (2020, 10 Eylül). Kurucaşile Belediyesi Resmi Web Sitesi, Erişim adresi https://www.kurucasile.bel.tr/

Kurucaşile Kaymakamlığı. (2020, 11 Eylül). T.C. Kurucaşile Kaymakamlığı, Erişim adresi, http://www.kurucasile.gov.tr/

Lash, S. and Urry, J. (1994). Economies of Signs \& Space, Sage Publ., London.

Önemli, S. (2007). Stratejik planlama - kentsel projeler iliskisi ve kentsel kiyi tasarimi: istanbul tarihi yarimada kiyi bandi üzerine bir irdeleme, Yüksek Lisans Tezi, Mimar Sinan Güzel Sanatlar Üniversitesi Fen Bilimleri Enstitüsü, İstanbul.

Van der Ryn, S., Cowan, S. (1996). Ecological Design, Island Pres, California, 202 p. 